\title{
Pengaruh Teknologi Informasi Dan Pengawasan Keuangan Terhadap Nilai Informasi Laporan Keuangan Pemerintah Daerah
}

\author{
Muhamad Rifandi \\ Universitas 'Aisyiyah Yogyakarta
}

\begin{abstract}
Usefulness of the information can be measured by it quality and it is be used in the decision making. This study aimed to analyse the factors affecting the information value of financial statements of local governments, there are the use of information technology and financial supervision area. This research used the survey method and used primary data which obtained from the population of the Head of Sub Division of Accounting in each SKPD in districts of DIY. The collection of data through questionnaires and processed using the application SmartPLS 2.0. The Results of this study indicate that the use of information technology and financial oversight of local governments significantly influence the value of the local government's financial statement information.
\end{abstract}

Keywords: Value of information, information technology, financial control

\section{PENDAHULUAN}

\section{Latar Belakang}

Akuntabilitas dapat diartikan sebagai bentuk kewajiban mempertanggungjawabkan atas keberhasilan dan kegagalan pelaksanaan misi organisasi dalam mencapai tujuan dan sasaran yang telah ditetapkan sebelumnya, melalui suatu media pertanggungjawaban yang dilakukan secara periodik (Stanbury, 2003 dalam Mardiasmo, 2006).

Bentuk laporan pertanggungjawaban Pemerintah Daerah atas pengelolaan APBD selama satu tahun anggaran adalah dalam bentuk Laporan Keuangan Pemerintah Daerah (LKPD), yang terdiri dari Laporan Realisasi Anggaran, Neraca, Laporan Arus Kas, dan Catatan Atas Laporan Keuangan. LKPD tersebut harus disusun sesuai Standar Akuntansi Pemerintah yang terkandung di dalam Peraturan Pemerintah Nomer 24 Tahun 2005.

Corresponding Author:

Email : muhamadrifandi@unisayogya.ac.id 
Menggambarkan aktivitas pemerintah yang dituangkan di dalam laporan keuangan merupakan upaya transparansi yang dilakukan oleh pemerintah untuk mewujudkan akuntabilitas yang berupa keterbukaan perintah dalam mengelola sumber daya publik, agar masyarakat dapat mengukur kinerja pemerintah. Transparansi informasi terutama informasi keuangan dan fiskal harus dilakukan dalam bentuk yang relevan dan mudah dipahami (Schiavo-Campo and Tomasi, 1999 dalam Mardiasmo, 2006).

Dalam pengelolaan keuangan, pemerinntah melakukan berbagai reformasi keuangan publik dengan mengeluarkan Undang-Undang Nomer 17 Tahun 2003 tentang Keuangan Negara yang mensyaratkan bentuk dan isi laporan pertanggungjawaban pelaksanaan Anggaran Pendapatan dan Belanja Negara (APBN) atau Anggaran Pendapatan dan Belanja Daerah (APBD) disusun dan dilaporkan sesuai standar akuntansi pemerintah yang telah ditetapkan dalam Peraturan Pemerinta Nomer 24 Tahun 2005 tentang Standar Akuntansi Pemerintahan (SAP). Yang menjadi dasar teknis pengelolaan keuangan daerah adalah Peraturan Mentri Dalam Negeri Nomer 13 tahun 2006 yang berlaku sejak tanggal 1 januari 2007.

Kebermanfaatan sesuatu hal termasuk informasi merupakan suatu karakteristik yang hanya dapat dinilai pada sisi kualitatif, yang mana menghubungkan antara keputusan, pemakaian dan keyakinan pengguna informasi itu sendiri. Dalam Rerangka Konseptual Akuntansi Pemerintahan (PP No. 24 Tahun 2005) menjelaskan kriteria dan unsur-unsur yang melatarbelakangi terbentuknya kualitas informasi yang menjadikan nilai informasi laporan keuangan pemerintah semakin baik adalah: (i) relevan, (ii) andal, (iii) dapat dibandingkan, dan (iv) dapat dipahami.

Perkembangan teknologi informasi sangat cepat dari masa ke masa, maka dipandang perlu pemerintah daerah memanfaatkan perkembangan tersebut untuk membantu penyusunan LKPD sesuai ketentuan yang ada. Pemanfaatan teknologi informasi yang dimaksud mencakup (a) pengolahan data, pengolahan informasi, sistem manajemen dan proses kerja secara elektronik dan (b) pemanfaatan kemajuan teknologi informasi agara pelayanan publik dapat diakses secara mudah dan murah oleh masyarakat di seluruh wilayah negeri ini (Hamzah, 2009).

Selain pemanfaatan teknologi informasi, pengawasan keuangan daerah dipandang penting untuk meningkatkan nilai informasi yang terkandung di dalam LKPD, dimana dalam penggunaan anggaran agar dapat terealisasi sesuai rencana dan tertib dalam pertanggungjawabannya.

Berdasarkan paparan di atas, peneliti bermaksud melakukan penelitian dengan judul 
"Pengruh pemanfaatan teknologi informasi dan pengawasan keuangan daerah terhadap nilai informasi laporan keuangan daerah".

\section{Tujuan Penelitian}

Tujuan penelitian ini untuk menganalisis pengaruh pemanfaatan teknologi informasi dan pengawasan keuangan daerah terhadap nilai informasi laporan kueangan pemerintah daerah.

\section{Kontribusi Penelitian}

Penelitian ini berkontribusi sebagai bahan acuan dan pertimbangan pemerintah daerah dalam upaya peningkatan nilai informasi laporan keuangan pemerintah daerah.

\section{TINJAUAN PUSTAKA}

\section{Decision-Usefulness Theory}

Kegunaan-keputusan informasi akuntansi mengandung komponen-komponen yang perlu dipertimbangkan oleh para penyaji informasi akuntansi agar cakupan yang ada dapat memenuhi kebutuhan para pengambil keputusan yang akan menggunakannya. SFAC No. 2 tentang Qualitative Characteristics of Accounting Information menggambarkan hirarki dari kualitas informasi akuntansi dalam bentuk kualitas primer, kandungannya dan kualitas sekunder.

Teori kegunaan-keputuan informasi sangat relevan, karena Standar Akuntansi Pemerintah di Indonesia mengadopsi karakteristik kualitatif dari SFAC No.2. Hanya saja SAP menekankan pada empat prasyarat normatif yakni: relevan, andal, dapat dibandingkan, dan dapat dipahami. Untuk karakteristik konsistensi, menjadi bagian dari prinsip akuntansi dan pelaporan keuangan.

\section{Nilai Informasi}

Hal yang ingin didapatkan para stakeholder dari LKPD adalah informasi yang relevan sesuai dengan keputusan yang ingin dibuat. Inilah alasan agar pemerintah harus mengedepankan manfaat dan tujuan penyajian laporan keuagan agar informasi tersebut tidak menjadi sia-sia. Mengatakan bahwa informasi harus bermanfaat bagi para pemakai sama saja dengan mengatakan bahwa informasi harus mempunyai nilai (Surwardjono, 2005).

Kebermanfaatan sebuah informasi dapat diukur dari kualitas nilai informasi dan berguna dalam pengambilan keptusan. Kualitas laporan keuagan tersebut tercermin dalam karakteristik kualitatif Komite Standar Akuntansi Pemerintah (2005) yang menjelaskan bahwa karakteristik kualitatif laporan keuangan adalah ukuran-ukuran normatif yang perlu 
diwujudkan dalam informasi akuntansi agar dapat memenuhi tujuannya. Persyaratan normatif agar laporan keuangan pemerinntah pusat/daerah dapat memenuhi kualitas yang dikehendaki adalah relevan, andal, dapat dibandingkan dan dapat dipahami.

\section{Pemanfaatan Teknologi Informasi}

Tuntutan penggunaan SIKD oleh Pemerintah Daerah agar mampu memanfaatkan semua jenis informasi dan teknologi Komputer untuk memberikan informasi dan layanan pemerintah kepada masyarakat. Pemanfaatan Teknologi Informasi dalam akuntansi dapat mempengaruhi kepuasan para pengguna laporan keuangan karena kualitas, kecepatan, dan keakuratan data yang terkandung dalam laporan keuangan tersebut.

Pemerintah melalui Peraturan Pemerintah Nomor 56 tahun 2005 menjelaskan bahwa Pemerintah dan Pemerintah Daerah berkewajiban untuk mengembangkan dan memanfaatkan kemajuan teknologi informasi untuk meningkatkan kemampuan mengelola keuangan daerah, dan menyalurkan informasi keuangan daerah kepada pelayanan publik. Dengan mamanfaatkan kemajuan teknologi informasi yang begitu pesat, maka memberi kesempatan kepada semua pihak untuk mengakses, mengelola, dan menggunakan informasi yang terdapat dalam Laporan Keuangan Pemerintah Daerah dengan cepat dan akurat.

Arfianti (2011), menemukan bahwa pemanfaatan pemanfaatan teknologi informasi yang meliputi teknologi komputer dan teknologi komunikasi dalam pengelolaan keuangan daerah, dapat mempercepat proses pengolahan data transaksi, keakurasian dalam peritungan, serta menghasilkan output lainnya lebih bias tepat waktu. Temuan ini didukung oleh penelitian Winidyaningrum (2010), Indriasari (2010) dan Indrawati (2013) yang menjelaskan bahwa pemanfaatan teknologi informasi dalam pengolahan data memiliki keunggulan dalam kecepatan sehingga menghasilkan laporan keuangan yang tepat waktu, serta kecepatan dalam pemrosesan informasi.

Berdasarkan paparan di atas yang menjelaskan tentang adanya pengaruh pemanfaatan teknologi informasi terhadap nilai informasi laporan keuangan pemerintah daerah. Sehingga di dalam penelitian ini, peneliti kembali menguji dengan hipotesis sebagai berikut:

H1: Pemanfaatan teknologi informasi berpengaruh secara positif terhadap nilai inforasi laporan keuangan

\section{Pengawasan Keangan Daerah}


Menurut Yosa (2010) dalam Arfianti (2011) yang dimaksud dengan pengawasan adalah suatu upaya yang sistematik untuk menetapkan kinerja standar pada perencanaan untuk merancang sistem umpan balik informasi, untuk membandingkan kinerja aktual dengan standar yang telah ditentukan, untuk menetapkan apakah telah terjadi suatu penyimpangan, serta untuk mengambil tindakan perbaikan yang diperlukan untuk menjamin bahwa sumber data organisasi atau pemerintahan telah digunakan seefektif dan seefisien mungkin guna mencapai tujuan organisasi atau pemerintahan.

Keputusan Presiden Nomor 74 Tahun 2001 tentang Tata Cara Pengawasan Penyelenggaraan Pemerintahan Daerah. Dalam pasal 1 ayat (6) menjelaskan bahwa pengawasan adalah proses kegiatan yang ditujukan untuk menjamin agar pemerintah daerah berjalan sesuai dengan rencana dan ketentuan peraturan perundang-undangan yang berlaku, dan selanjutnya akan menghasilkan laporan keuangan pemerintah daerah yang mempunyai kandungan nilai informasi yang berkualitas.

Hasil penelitian Arnando (2013) menemukan bahwa pengaruh pengawasan keuangan terhadap nilai informasi LKPD pada semakin baik pengawasan keuangan daerah, maka nilai informasi yang dihasilkan akan semakin baik pula. Pengawasan juga mampu membantu pemerintah dalam upaya mencapai tujuan ogranisasi secara efektif dan efisien. Hal ini sejalan dengan penelitian Indrawati (2013) yang menjelaskan bahwa pengawasan keuangan berpengaruh positif signifikan terhadap nilai informasi laopran keuangan pemerintah daerah.

Berdasarkan uraian di atas mengenai pengaruh pengawasan keuangan daerah terhadap nilai informasi laporan keuangan pemerintah daerah, peneliti membuat turunan hipotesis sebagai berikut:

H2: Pengawasan keuangan daerah berpengaruh secara positif terhadap nilai informasi

\section{laporan keuangan}

\section{Model Penelitian}

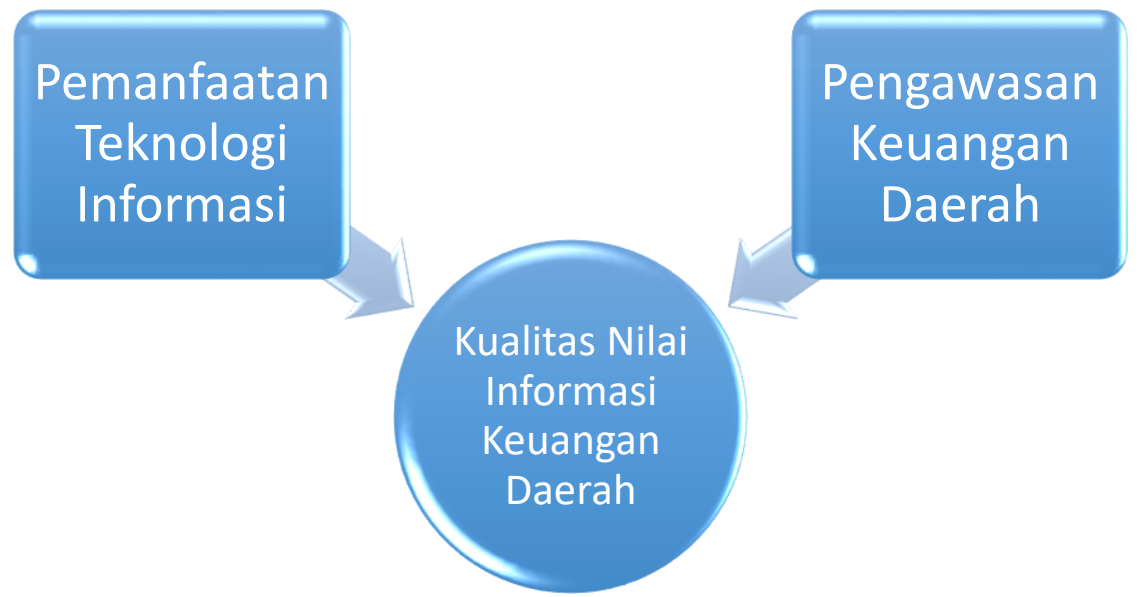




\section{METODE PENELITIAN}

\section{Populasi dan Sampel Penelitian}

Obyek penelitian yang digunakan dalam penelitian ini adalah Satuan Kerja Perangkat Daerah (SKPD) sebagai pengguna anggaran yang harus dilaporkan dalam bentuk Laporan Keuangan Pemerintah Daerah (LKPD). Sedangkan subyek penelitian dalam penelitian ini adalah sub bagian keuangan/akuntansi dari tiap-tiap SKPD yang bertindak sebagai pencatat masuk dan keluarnya anggaran dan selanjutnya menyusun transaksi tersebut ke dalam LKPD.

Sampel dalam penelitian ini adalah Kepala sub bagian keuangan/akuntansi yang berada di SKPD Pemerintah Kabupaten Kota Se-Propinsi Daerah Istimewa Yogyakarta (DIY) yang terdiri dari Pemerintah Kota Jogja, Pemerintah Daerah Kabupaten Sleman, Kabupaten Bantul, Kabupaten Gunung Kidul dan Kabpaten Kulonprogo.

\section{Sumber dan Teknik Pengumpulan Data}

Data di dalam penelitian ini merupakan data primer, dimana peneliti membagikan langsung kuesioner kepada Kepala sub bagian Akuntansi SKPD di Kabubaten Kota seDIY. Selain membagikan kuesioner, dalam teknik pengumpulan data peneliti juga melakukan observasi, dimana peneliti melakukan pengamatan secara langsung mengenai aktivitas dan fasilitas yang ada di SKPD yang bersangkutan.

\section{Uji Instumen Data}

Uji validitas dilakukan terhadap seluruh pernyataan yang ada dalam setiap variabel, yaitu untuk mengetahui tingkat kevalidan setiap pernyataan terhadap variabel penelitian. Untuk menaksir validasi item pernyataan, penelitian ini menggunakan Confirmatory Factor Analysis (CFA), dengan pendekatan Partial Least Square (PLS). Varian yang didasarkan pada pendekatan PLS lebih sering digunakan karena PLS tidak mengharuskan pembebanan sampel dan merupakan distribusi bebas. Suatu instrument dikatakan valid kalau loading factor harus lebih besar dari 0,5 (Ghozali, 2011).

Uji reliabilitas dalam penelitian ini dimaksudkan untuk mengetahui sejauh mana hasil pengukuran tetap konsisten, apabila dilakukan pengukuran dua kali atau lebih terhadap gejala yang sama dengan menggunakan alat pengukur yang sama pula. Peneliti melakukan uji reliabilitas konstruk dengan menampilkan nilai composite reliability, Average Variance Extracted (AVE) dan membandingkan nilai akar AVE dengan nilai korelasi antar konstruk. Instrumen yang dipakai dalam variabel dikatakan andal (reliable) apabila composite reliability memiliki nilai di atas 0.80 dan nilai AVE di atas 0.50 (Ghozali, 2011). 


\section{Pengujian Hipotesis Penelitian}

Pengujian seluruh hipotesis penelitian menggunakan metode Partial Least Square (PLS). Dengan metode PLS, maka model yang diuji dapat mempergunakan asumsi bahwa data tidak harus berdistribusi normal, skala pengukuran dapat berupa nominal, ordinal, interval, maupun rasio. Jumlah sampel tidak harus besar dan indikator tidak harus dalam bentuk refleksif karena dapat pula berbentuk formatif, serta model tidak harus berdasarkan teori.

Uji t digunakan untuk menguji signifikansi konstanta dan variabel independen yang terdapat dalam persamaan tersebut secara individu apakah berpengaruh terhadap nilai variabel dependen. Pengujian ini dilakukan dengan melihat output dengan bantuan program aplikasi smartPLS. Jika nilai t-hitung > t-tabel (1.99), pada taraf signifikansi 5\% maka diterima atau signifikan. Pengukuran persentase pengaruh semua variabel independen terhadap nilai variabel dependen ditunjukkan oleh besarnya koefisien determinasi R-square

$\left(\mathrm{R}^{2}\right)$ antara satu dan nol, dimana nilai $\mathrm{R}$-square $\left(\mathrm{R}^{2}\right)$ yang mendekati satu memberikan persentase pengaruh yang besar (Ghozali, 2006).

\section{HASIL DAN PEMBAHASAN}

\section{Gambaran Umum Obyek/Subyek Penelitian}

Responden dalam penelitian ini adalah Kepala sub bagian keuangan Dinas dan Badan yang ada di lingkungan Kabupaten Kota se-DIY, yaitu: Kota Yogyakarta sebanyak 16 responden, Kabupaten Sleman sebanyak 17 responden, Kabupaten Bantul sebanyak 22 responden, Kabupaten Kulon Progo sebanyak 19 responden, dan Kabupaten Gunung Kidul sebanyak 17 responden. Beberapa kesempatan peneliti mendapat kesempatan bertemu dengan kepala sub bagian keuangan untuk membahas beberapa poin indikator pernyataan yang ada di kuesioner, dan yang lain dititipkan melalui Sekretariat/Bagian umum.

\section{Deskripsi Responden}

Dari kuesioner yang dibagikan kepada responden, namun tidak semua kembali ke tangan peneliti untuk dianalisis. Berikut prosentase tingkat pengembalian kuesioner: 
Tabel 1. Tingkat Pengembalian Kuesioner

\begin{tabular}{|l|c|}
\hline \multicolumn{1}{|c|}{ Keterangan } & Jumlah \\
\hline Kuesioner yang dibagikan & 91 \\
\hline Kuesioner yang tidak direspon & 16 \\
\hline Kuesioner yang direspon & 75 \\
\hline Kuesioner yang tidak dapat digunakan & 0 \\
\hline Kuesioner yang dapat digunakan & 75 \\
\hline Tingkat pengembalian kuesioner & $\mathbf{7 5 / 9 1 \times 1 0 0 \% = 8 2 \%}$ \\
\hline
\end{tabular}

Sumber: data yang diolah

\section{Evaluasi Pengukuran (Outer Model)}

\section{Uji validitas}

Validitas pertanyaan secara individual dapat di lihat pada tabel Cross Loading di bawah ini.

Tabel. 2 Uji Validitas

\begin{tabular}{|l|l|l|l|}
\hline & \multicolumn{1}{|c|}{ NILK } & \multicolumn{1}{c|}{ PKD } & PTI \\
\hline A1 & 0.798066 & 0.704550 & 0.696053 \\
\hline A2 & 0.859170 & 0.708639 & 0.544212 \\
\hline A3 & 0.929323 & 0.719230 & 0.544783 \\
\hline A4 & 0.903966 & 0.684299 & 0.598564 \\
\hline A5 & 0.926947 & 0.715309 & 0.604359 \\
\hline A6 & 0.916279 & 0.730969 & 0.551512 \\
\hline A7 & 0.890304 & 0.700501 & 0.587251 \\
\hline A8 & 0.800628 & 0.670773 & 0.531920 \\
\hline B1 & 0.751580 & 0.688787 & 0.613222 \\
\hline B2 & 0.767984 & 0.535946 & 0.522785 \\
\hline B3 & 0.848542 & 0.713694 & 0.586299 \\
\hline PKD1 & 0.696135 & 0.852232 & 0.673707 \\
\hline
\end{tabular}

\begin{tabular}{|l|l|l|l|}
\hline PKD2 & 0.711157 & 0.913371 & 0.609831 \\
\hline PKD3 & 0.756773 & 0.929569 & 0.585436 \\
\hline PKD4 & 0.724102 & 0.913090 & 0.636327 \\
\hline PKD5 & 0.754055 & 0.930866 & 0.609831 \\
\hline PKD6 & 0.655773 & 0.824672 & 0.603284 \\
\hline PKD7 & 0.759376 & 0.897730 & 0.703964 \\
\hline PTI1 & 0.556554 & 0.541631 & 0.817954 \\
\hline PTI2 & 0.523893 & 0.532929 & 0.757914 \\
\hline PTI3 & 0.668068 & 0.651186 & 0.869190 \\
\hline PTI4 & 0.575533 & 0.592434 & 0.781860 \\
\hline PTI5 & 0.551492 & 0.565457 & 0.848911 \\
\hline PTI6 & 0.406252 & 0.492801 & 0.802897 \\
\hline PTI7 & 0.478226 & 0.560426 & 0.736094 \\
\hline
\end{tabular}

Sumber: Data primer diolah

Keterangan: NILK : Nilai Informasi Laporan

Keuangan

PKD : Pengawasan Keuangan Daerah

PTI : Pemanfaatan Teknologi

Informasi

Berdasarkan tabel di atas, dapat dilihat bahwa loading factor lebih besar dari 0.50. Hal ini menandakan bahwa semua item pertanyaan secara individual adalah valid. 


\section{Uji Realibilitas}

Untuk melihat reliabel atau tidak suatu instrumen penelitian dapat dilihat pada tabel berikut:

Tabel 3. Composite Realibility

\begin{tabular}{|l|l|c|c|}
\hline & $\begin{array}{l}\text { Composite } \\
\text { Reliability }\end{array}$ & AVE & $\begin{array}{c}\text { Akar } \\
\text { AVE }\end{array}$ \\
\hline KILK & 0.967783 & 0.733002 & 0.85616 \\
\hline PKD & 0.965782 & 0.801556 & 0.89530 \\
\hline PTI & 0.927001 & 0.645344 & 0.80333 \\
\hline \multicolumn{2}{l}{ Sumber: Data primer diolah }
\end{tabular}

Reliabilitas yang baik mensyaratkan bahwa nilai composite reliability di atas 0.80 dan nilai AVE di atas 0.50. Berdasarkan tabel di atas, dapat dilihat bahwa semua konstruk memiliki reliabilitas yang baik, karena nilai composite reliability $>0.80$ dan nilai AVE $>0.50$.

\section{Evaluasi Model Struktur (Inner Model)}

Setelah model yang diperkirakan sudah memenuhi kriteria outer model, selanjutnya dilakukan pengujian model struktur, sebagaimana tabel berikut:

Tabel 4. R Square Value Untuk Model Nilai

Informasi Laporan Keuangan

\begin{tabular}{|l|l|}
\hline & R Square \\
\hline KILK & 0.677197 \\
\hline PKD & \\
\hline PTI & \\
\hline
\end{tabular}

Sumber: Data primer diolah

Berdasarkan tabel di atas, dapat dilihat nilai R Square untuk variabel Nilai Informasi Laporan Keuangan (NILK) adalah sebesar 0.677, yang artinya variabel konstruk NILK dijelaskan oleh konstruk Pemanfaatan Teknologi Informasi dan Pengawasan Keuangan Daerahh sebesar $67.7 \%$, sedangkan sisanya dijelaskan oleh konstruk lain sebesar $32.3 \%$. 


\section{Pengujian Hipotesis}

Pengujian hipotesis dan hubungan antar variabel dapat dilihat hasil path coefficients berikut ini:

Tabel 5. Hasil path coefficients

\begin{tabular}{|c|c|c|c|c|}
\hline $\begin{array}{c}\text { Hipotesi } \\
\text { s }\end{array}$ & Path & $\begin{array}{c}\text { Path } \\
\text { Coefficie } \\
\text { nt }\end{array}$ & $\begin{array}{c}\text { T } \\
\text { Statistics }\end{array}$ & $\begin{array}{c}\text { Keteranga } \\
\mathrm{n}\end{array}$ \\
\hline $\mathrm{H} 1$ & PTI $\rightarrow$ NILK & 0.218611 & 2.638644 & Didukung \\
\hline H2 & $\begin{array}{c}\text { PKD } \rightarrow \\
\text { NILK }\end{array}$ & 0.654002 & 6.565833 & Didukung \\
\hline
\end{tabular}

Sumber: Data primer diolah

Dari tabel di atas, kedua variabel memiliki nilai $t$-value $>t$-table (1.99), yang artinya kedua hipotesis didukung. Selain tabel di atas, dapat juga dilihat dari model penelitian yang sudah disesuaikan dengan format SmartPLS sebagai berikut:

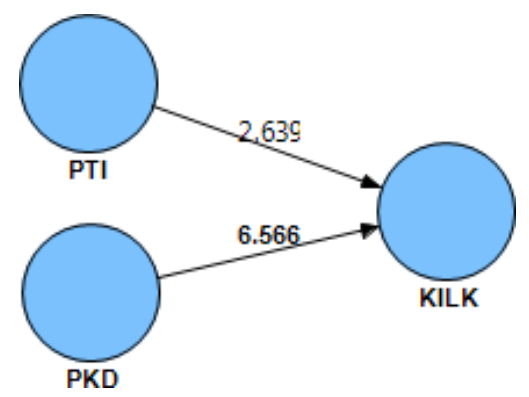

Gambar 1. Model Penelitian

\section{Pembahasan}

\section{Pengujian hipotesis 1}

Hipotesis pertama (H1) menyatakan bahwa pemanfaatan teknologi informasi berpengaruh terhadap nilai informasi laporan keuangan pemerintah daerah. Berdasarkan tabel di atas memiliki nilai path coefficient sebesar 0.218611 dan $t$-value sebesar 2.638644 . Hal ini menunjukkan bahwa t-value (2.638644) > t-table (1.99) yang berarti hipotesis pertama didukung.

Hipotesis pertama didukung yang bearti pemanfaatan teknologi informasi berpenaruh signifikan terhadap nilai informasi laporan keuangan pemerintah daerah. Hal ini didukung oleh hasil penelitian yang dilakukan oleh Winidyaningrum (2010), Indriasari (2010), Arfianti (2011) dan Indrawati (2013) yang menjelaskan bahwa pemanfaatan teknologi informasi dalam pengolahan data memiliki keunggulan dalam kecepatan sehingga menghasilkan laporan keuangan yang tepat waktu, serta kecepatan dalam pemrosesan 
informasi.

\section{Pengujian hipotesis 2}

Hipotesis kedua (H2) menyatakan bahwa pengawasan keuangan daeraah berpengaruh terhadap nilai informasi laporan keuangan pemerintah daerah. Berdasarkan tabel di atas memiliki nilai path coefficient sebesar 0.654002 dan $t$-value sebesar 6.565833 . Hal ini menunjukkan bahwa $t$-value $(6.565833)>t$-table (1.99) yang berarti hipotesis kedua didukung.

Hipotesis kedua didukung menunjukkan bahwa pengawasan keuangan daerah berpengaruh signifikan terhadap kualitas nilai informasi laporan keuangan pemerintah daerah. Hal ini sejalan dengan hasil penelitian yang dilakukan oleh Arnando (2013) yang menemukan bahwa pengaruh pengawasan keuangan terhadap nilai informasi laporan keuangan pemeraintah daerah, semakin baik pengawasan keuangan daerah, maka nilai informasi yang dihasilkan akan semakin baik pula. Hal serupa disampaikan pada hasil penelitian Indrawati (2013) yang menjelaskan bahwa pengawasan keuangan berpengaruh positif signifikan terhadap nilai informasi laopran keuangan pemerintah daerah.

\section{KESIMPULAN}

Berdasarkan analisa dan pembahasan di atas, dapat disimpulkan ke dalam dua poin berikut. Pertama, pemanfaatan teknologi informasi berpengaruh signifikan terhadap kualitas nilai informasi laporan keuangan pemerintah daerah. Hal ini disebabkan pegawai lebih senang memanfaatkan teknologi informasi untuk mempercepat dan mempermudah kinerjanya. Kedua, pengawasan keuangan daerah berpengaruh signifikan terhadap kualitas nilai informasi laporan keuangan pemerintah daerah. Hal ini disebabkan pengawasan keuangan daerah diperioritaskan untuk mendapatkan keyakinan yang wajar terhadap efektivitas dan efisiensi organisasi, keandalan pelaporan keuangan, dan kepatuhan terhadap peraturan perundang-undangan.

\section{DAFTAR PUSTAKA}

Alimbudiono, Ria Sandra \& Fidelis Arastyo Andono, (2004) "Kesiapan Sumber Daya Manusia Sub Bagian Akuntansi Pemerintah Daerah "XYZ” dan Kaitannya Dengan Pertanggungjawaban Keuangan Daerah Kepada Masyarakat: Renungan Bagi Akuntan Pendidik", Jurnal Akuntansi dan Keuangan Sektor Publik, Vol. 05 No. 02 Arfianti, Dita, (2011) “Analisis Faktor-Faktor Yang Mempengaruhi Nilai Informasi Pelaporan Keuangan Pemerintah Daerah", Skripsi, Universitas Diponegoro, 


\section{Semarang.}

Armando, Gerry, (2013) "Pengaruh Sistem Pengendalian Intern Pemerintah dan Pengawasan Keuangan Daerah Terhadap Nilai Informasi Laporan Keuangan Pemerintah di Kota Bukittinggi”, Artikel, Universitas Negeri Padang.

Dwiandra, (2006) "Pengaruh Interaksi Ketidakpastian Lingkungan, Desentralisasi, dan Aggregat Informasi Akuntansi Manajemen terhadap Kinerja Manajerial”, Symposium Nasional akuntansi IX. Padang.

Ghozali, I, (2006) “Aplikasi Analisis Multivariate dengan Program SPSS”, Penerbit Universitas Diponegoro, Semarang.

Hamzah, Ardi, (2009) "Pengaruh Ekspektasi Kinerja, Ekspektasi Usaha, Faktor Sosial, Kesesuaian Tugas dan Kondisi yang Memfasilitasi Pemakai terhadap Minat Pemanfaatan Sistem Informasi”, Simposium Nasional Sistem Teknologi Informasi, UGM.

Hevesi, G. Alan, (2005) "Standards for Internal Control in New York State Government", www.osc.state.ny.us

Hevesi, G. Alan, (2005) "Standards for Internal Control in New York State Government”. www.osc.state.ny.us.

Indrawati, Dwi Anita., Mohamad Djasuli., Anita Carolina, (2013) "Analisis faktor-faktor yang mempengaruhi nilai informasi pelaporan keuangan pemerintah daerah" Jurnal Universitas Trunojoyo, Madura.

Indriasari, Desi dan Ertambang Nahartyo, (2008) "Pengaruh kapasitas sumberdaya manusia, pemanfaatan teknologi informasi, dan pengendalian intern akuntansi terhadap nilai informasi pelaporan keuangan pemerintah daerah”, SNA XI Pontianak

Kharis, Abdul, (2010) "Pengaruh Kualitas Sumber Daya manusia Terhadap Pelaksanaan Sistem Pengendalian Intern pada PT. Avia Avian”, Skripsi, UPN Veteran, Jawa Timur.

Kiswara, Endang, (2011) "Nilai Relevan Dan Reliabilitas Kegunaan-Keputusan Informasi Akuntansi Menurut Sfac No. 2 Dalam Penyajian Laporan Keuangan Dengan MetodeMetode Pembebanan Pajak Penghasilan Berbeda", PhD thesis, Universitas Diponegoro, Semarang.

Komite Standar Akuntansi Pemerintahan, (2005) "Peraturan Pemerintah Nomor 24 Tahun 2005 tentang Standar Akuntansi Pemerintahan".

Mardiasmo, (2006) "Perwujudan Transparansi dan Akuntabilitas Publik Melalui Akuntansi 
Sektor Publik: Suatu Sarana Good Governance”, Jurnal Akuntansi Pemerintah, Vol. 2 No.1

Mulyadi, (2005) “Akuntansi Manajemen: Konsep, Manfaat dan Rekayasa”, Edisi Kedua, Yogyakarta: BPFE.

Noviyanti, Suzy dan Intiyas Utami, (2004) “Dasar-dasar Pengauditan”, Fakultas Ekonomi Universitas Kristen Satya Wacana, Salatiga.

Republik Indonesia, Ikhtisar Hasil Pemeriksaan Semester I 2014 Badan Pengawas Keuangan, http://bpk.go.id/ihps

Republik Indonesia, Keputusan Presiden nomor 74 Tahun 2001 tentang Tata Cara Pengawasan Penyelenggaraan Pemerintahan Daerah.

Republik Indonesia, Peraturan Mentri Dalam Negeri Nomer 13 tahun 2006 tentang teknis pengelolaan keuangan daerah.

Republik Indonesia, Peraturan Pemerintah nomor 56 tahun 2005 tentang Sistem Informasi Keuangan Daerah.

Republik Indonesia, Peraturan Pemerintah Nomor 60 Tahun 2008 "tentang Sistem Pengendalian Intern Pemerintah".

Republik Indonesia, Peraturan Pemerintah Nomor 71 Tahun 2010 "tentang Standar Akuntansi Pemerintahan”.

Republik Indonesia, Peraturan Pemerintah nomor 8 tahun 2006 tentang Pelaporan Keuangan dan Kinerja Instansi Pemerintah.

Republik Indonesia, Undang-Undang nomor 17 tahun 2004 tentang Keuangan Negara.

Sukmaningrum, Tantriani dan Puji Hartono, (2011) "Analisis faktor-faktor yang mempengaruhi kualitas informasi laporan keuangan pemerintah daerah", Skripsi, Universitas Diponegoro, Semarang.

Sutabri, Tata (2003) “Analisa Sistem Informasi”, Penerbit Andi, Yogjakarta

Tuasikal, Askam, (2007) "Pengaruh Pemahaman Sistem Akuntansi Pengelolaan Keuangan Daerah terhadap Kinerja Satuan Kerja Pemerintah Daerah", Jurnal Akuntansi dan Keuangan Sektor Publik, Vol.08, No.01.

Warisno, (2008) "Faktor-Faktor yang Mempengaruhi Kinerja Satuan Kerja Perangkat Daerah (SKPD) di Longkungan Pemerintah Provinsi Jambi”, Tesis, Sekolah Pascasarjana USU, Medan.

Winidyaningrum, C dan Rahmawati (2010) "Pengaruh sumberdaya manusia dan pemanfaatan teknologi informasi terhadap keterandalan dan ketepatwaktuan 
pelaporan keuangan pemerintah daerah dengan variabel intervening pengendalian intern akuntansi”, SNA XIII Purwokerto

Xu, Hongjiang, Jeretta H.N., G. Daryl Nord., Binshan Lin, (2003) “Key issue of accounting information quality management: Australian case studies", Industrial Mangaement \& Data System

Yani, Ahmad, (2002) "Hubungan Keuangan Antara Pemerintahan Pusat dan Daerah di Indonesia", Rajawali Pers, Jakarta.

Yuliani, Safrida., Nadirsyah., Usman Bakar, (2010) "Pengaruh pemahaman akuntansi, pemanfaatan sistem informasi akuntansi keuangan daerah dan peran internal audit terhadap kualitas laporan keuangan pemerintah daerah", Jurnal telaah dan riset akuntansi, Vol. 3, No. 2 